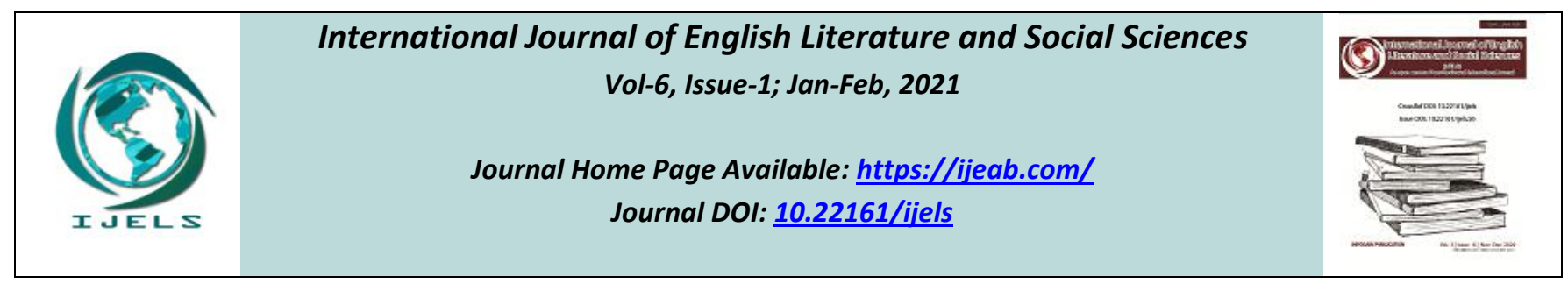

\title{
The Role of the Infographic in the Electronic Portals of Egypt's National Press in Dealing with the Economic Development
}

\author{
Dr. Sally Shehata
}

King Faisal University, Saudi Arabia

Received: 19 Nov 2020; Received in revised form: 03 Jan 2021; Accepted: 17 Jan 2021; Available online: 29 Jan 2021 (C)2021 The Author(s). Published by Infogain Publication. This is an open access article under the CC BY license (https://creativecommons.org/licenses/by/4.0/).

\begin{abstract}
The study deals with the qualitative analysis of the infographic in three electronic portals of the Egypt's national press. It focuses on the utilizing the infographic in dealing with economic development. One of the study's outcomes is that the superficial addressing of such issues counts on just statistics and figures without analyzing or explaining. The sample websites depended on the government sources of information only and used the infographic for advertising the attitudes of the government.
\end{abstract}

Keywords-Electronic press portals, Egypt's national press, Economic development, Infographic.

\section{INTRODUCTION}

These days, the Egyptian economy is going through many major problems that require suggestion of solutions on the part of all institutions. This study does not mean to highlight the problems in detail or make accusations against any institutions as the details are overwhelming and would consume much time. Rather, currently every citizen should start with themselves contributing to the economic development according to the economic liberal vision that postulates that individualism is a means to an end, and the end is the good and flourishment of the society.

Reforming individuals is the main mission of the economic media which is seen as figures, statistics and complicated equations by people. In order to rectify this concept, the information of the economic development should be presented in an attractive and simple way, and also should be presented in various forms so that all types of people can be satisfied in the age of the digital media which expose people to visual materials more than written ones. And because people always prefer visual materials, the infographic becomes more important in terms of simplifying the economic information.

\section{Conceptual Framework:}

Previous studies, Researches, Foreign studies

\section{Study of Kaleyn Godoy, 2015}

This study illustrates how the infographic addresses a huge burning over a wide area in Arizona State in 2013. Nineteen firemen were killed in that burning. The study presents a general view of the process used for designing that infographic as it summarizes the techniques of collecting data and giving pictures in a better way. Based on that, the study has given some details on the opportunities of the future design related to that topic.

\section{The Study of Siricharoen, 2015}

The objective of the study is defining the meaning of infographic and its usages, types and interactive effects. Also, the study has discussed the importance of the components of the infographic especially pictures, colors and designs. It presents information in a lovely attractive way. The study evaluates the infographic based on what it displays, its components and the types of pictures used in it.

\section{The study of Dick,2014}

The study aims at knowing the practices of making the interactive infographic in the news websites in the UK. In 
addition, the study has found out that the organizational regulations are controlling the traditional press criteria in the interactive infographic, and figures and statistics are the most used.

\section{The study of Dur, 2014}

The study has identified the usages of the infographic in press, its types, the way it displays its content and the differences between the fixed and the visual interactive designs. Also, the study has concluded that infographic has become a must in this age which cares more about visual communication in order to simplify the information and make it more understandable and appealing.

\section{The study of WaralakSiricharoen, 2013}

The study aims at identifying using infographic in the digital age for presenting news stories in an attractive way for those who prefer quick reading. Besides, the study shed some light on the tools of making infographic and concluded that it presents information within a limited frame and an artistic method. In general, infographic delivers information in an enjoyable way and easy to understand. Combining motion and audio elements sets a comprehensive concept of multimedia.

\section{The study of Milatz, 2013}

The study has worked on discovering the impact of the interactive infographic on the user's memory, and the researcher carried out experiments as a tool of identifying the types of effect (fixed, interactive, timetable) on recalling information. One of the experiments was an infographic of the map of Europe displaying the German immigration. 122 German speakers were involved in that experiment, and the outcome was that there was no correlation between interactive infographic and the overall recovery of the information and timetables proved to be less effective in recalling the information.

\section{The study of Giardina\& Medina, 2012}

The study aimed at identifying the impact of the infographic and disseminating it to the work departments of the media companies. Relying on some infographic models of those published on New York Times; both the electronic and the printed, the way it is used, its effect on the activities of the media organizations, analyzing 50 infographic models and having interviews with the designers, the study discovered that developing the interactive infographic requires setting up special departmentsto work independently and improve the abilities of the newspapers' readership.

\section{The study of Maren, 2011}

The study examined the history of the infographic, its types, and how it was used in British newspapers and magazines. The study handled five daily newspapers and two weekly magazines for two weeks. The outcome was that the infographic was used more in the newspapers than the magazines, and it is utilized to simplify complicated analysis, reinforce long stories and give an aesthetic appearance to the page.

\section{Researches, Arabic studies:}

\section{Jawad Ragheb, Infographic in the Palestinian Press, 2018:}

The study aims at identifying how far Al-resala newspaper is interested in infographic, the issues it deals with, its types, contents, sources and its publishing sites. According to this study, Al-resala pays more attention to using the infographic than the other Palestinian newspapers and focuses on main 4 issues; political, social, Palestinian factions and local elections. Based on that fact, infographic basically deals with local status.

\section{Abeer Mohammad Salem, Using the Infographic by the Palestinian Electronic Websites, 2018}

The study aims to identify the degree of interest of Palestinian websites in the art of infographic and its main fields,components and the most important issues and topics posed by infographic in the websites. The study revealed the varying degrees of interest in the infographic and that the focus was more on the visuals than the readings by $(70.7 \%)$.

\section{Ismael Ibrahim, The Role of the Infographic in Documenting the Revolution of January $25^{\text {th }}, 2011$}

The study aims to identify the importance of infographic as one of the modern arts in attracting the readership, and also identify its types, history and ways of design from January $1^{\text {st }}, 2011$ to December $31^{\text {st }}, 2011$. The two newspapers used in this study were Alahram and Almasry Today. Besides, the study proved that private newspapers use the infographic more the national ones, and they train their journalists on using and designing it.

The study of AlsayedBekhit, Infographics in the United Arab Emirates Newspapers, 2009

The study aims to identify the art of infographics in the UAE newspapers. It revealed that study papers did not use infographic properly or regularly. Although such papers employ foreign journalists, they use infographic in a limited way, and they do not have infographic departments. (AlsayedBekhit, 2009)

\section{The previous studie's concluded that the art of Infographics:}

-is assessed by what it represents and what is inside it

-has become a necessity in the age of visual communication

-makes challenging information more understandable 
-represents complicated information in an attractive and simple way

-gives a comprehensive concept of multimedia as it combines audio and motion elements, which is exciting

-provides the page with an aesthetic appearance

Based on the important role of infographic in dealing with the economic development on the news websites, we had to:

-enrich the Arabic library with a lot of studies that cope with the digital age and the cutting edge technology used in the mass media these days.

-simplify the information, figures, statistics of the economic development, and represent them in an appealing way for the digital age readership.

-realize the importance of infographic as it is a new editing and directing tool to the press and Arab news websites, and so Arabic studies are required for making progress in that field.

By doing so, we focus on howelectronic portals of Egypt's national press; the study sample, use the infographic in dealing with the economic development issues as we aim to:

-identify the value of the economic issues represented by infographic as against other issues

-identify the types, sources, elements and the geographical area of infographic and its artistic basis of covering the economic issues

-identify how the infographic uses colors and pictures how coherent its design is

-identify the used techniques for presenting the information of the economic development by infographic

-compare between the electronic portals; the study sample, for how to be used

\section{DATA AND METHODS}

We conducted a comparative study of three electronic portals of Egypt's national newspapers that were selected based on what previous researchers concluded:

-they hold an advanced rank in the field of Arab electronic press, and the largest readership as well. The readers increasingly trust the information of those newspapers (Ahmed Fathi 2017, Abduljawad Saeed 2014)

The portals are:

-The electronic portal of Al-Ahram newspaper.

- The electronic portal of Al-Akhbar newspaper.

-The electronic portal of Al-Jumhurayea newspaper.
During the period from $1 / 06 / 2018$ to $1 / 10 / 2018$

\section{Type of Study:}

The study is descriptive and aims to describe the phenomenon, identify its elements, components and data, analyze and explain them in order to provide a specific objective image of the phenomenon which is used by the researcher to describe "infographics" and how it deals with the economic development issues.

\section{Study Methods: \\ Media Survey Method:}

The researcher surveyed all the infographics that deal with the economic development on the websites of (the sample study) to identify the way it works in that regard.

\section{Comparison Method:}

Holding a comparison between the journalistic infographics in terms of dealing with the economic development on the three electronic portals of the sample study.

\section{Case Study Method:}

The researcher used it so as to collect complete data on the infographics of the study websites.

\section{The tools of the Study:}

\section{Content Analysis Form}

The researcher relied on the content analysis form of the infographics which deal with the economic development on the electronic portals of the national newspapers (the sample study). The form is divided into two categories:

The category of what is said: It contains the types of issues dealt with by the infographic and the technique used for that.

The category of how it is said: It contains the types of the infographics used in dealing with the economic development, issues, the geographical area, sources of information and other factors such colors and pictures.

\section{Procedures of honesty and consistency:}

The researcher used steps to verify truthfulness, namely the precise definition of all categories of analysis, identification of unit of analysis, method of measurement, presentation of form to judges.

\section{Used Statistical Methods:}

The researcher relied on the method of simple refining as she found out that it is the most appropriate for reaching the results of the study.

\section{Judges:}

Dr. Hassan Ali, Media Professor, Faculty of Arts, Minia University 
Dr. Jamal Abdel-Hai Al-Najjar, Professor of Journalisim, Faculty of Media, Al-Azhar University

Dr. Mari Madkour. Professor of Journalism, Dean of the Faculty of Information, 6th October University

Dr. Fawzi Abdul Ghani Khallaf. Professor of Journalism, Dean of the Faculty of Information, Pharos University

Dr. UmaimaOmran. Professor of Journalism and ViceDean of the Faculty of Information, 6th October University Dr. Thoraya Badawi. Professor of Public Relations, Faculty of Arts, King Saud University

Dr. Sami Al-Jamaan. Head of Information Department, Faculty of Arts, King Faisal University

Dr. Ismail Ibrahim, lecturer at the Department of Journalism, Faculty of Media, 6th October University

\section{Economic Development}

It is the optimal utilization of the available resources more consciously and efficiently and with a higher mental capacity of the individual, and the community to achieve self-sufficiency first, and then work to raise the level of national income per capita to improve the standard of living.

\section{Infographics:}

It is an integration of multimedia in a single template and presenting it to the public in an attractive way in order to make the information, data and statistics more memorable with the help ofmaps and graphics, images and colors. So designers should make their infographics as narratives that can be seen and heard by the audience.

Addressing the economic development issues has a special character compared to other political and societal issues as the economic ones are relatively complex, correlate variables, use statistics and figures, analyze data and cares about what is behind scenes.

The role of the infographic in dealing with issues of economic development in an attractive manner is as follows:

-Not only presenting numbers but converting them into appropriate visual forms.

-To provide analysis of data by providing it hierarchically to determine the most important of it so that the dealing appears as more coherent.

-To engage the citizen in the development process by providing a simple explanation of various developments in the economic reality.

-The utilization of topographic in an optimal waywhich ensures the quality of its design.

Infographic components consists of three parts:

- Visual elements

- Content elements

- Knowledge

Visual elements include colors, graphics, icons, signals, maps.

Content Elements: Contains texts, facts, statistics, timeframes, references

Knowledge: It is the transmission of a comprehensive message of information and facts through facts and conclusions to convey the story in full. (Jawad Ragheb, 2018)

Table.1: The infographic dealing with the economic development on the study websites:

\begin{tabular}{|c|c|c|c|c|c|c|c|c|}
\hline Type of issue & \multicolumn{2}{|c|}{ AlAhram } & \multicolumn{2}{|c|}{ AlAkhbar } & \multicolumn{2}{|c|}{$\begin{array}{c}\text { Aljumhuray } \\
\text { ea }\end{array}$} & \multicolumn{2}{|c|}{ Total } \\
\hline Economic development & No. & $\%$ & No. & $\%$ & No. & $\%$ & No. & $\%$ \\
\hline & 29 & 76 & 32 & 23 & 17 & 57 & 78 & 37.9 \\
\hline Others & 9 & 24 & 106 & 77 & 13 & 43 & 128 & 62.1 \\
\hline Total & 38 & 100 & 138 & 100 & 30 & 100 & 206 & 100 \\
\hline
\end{tabular}

From the above table, we can conclude that:

AkhbarAlyoum is excelling in using infographics as against other study websites. However, it is still relatively less than private news portals. The electronic portal of Aljumhureya is the least of them.

Ismail Raheel proved AlmasryAlyoum to be exceeding other portals of the national press, and that it provided its journalists with training of how to use to design infographics (Ismail Raheel 2015)

Also, Maren study (2011) proved that British newspapers (the 5 newspapers of the study) had infographics almost every day on them. Meanwhile, Emarati newspapers were noticed to be decreasing its use of the infographics according to the study of AlsayedBekhit 2009)( 
Table.2: The geographical areas of infographics

\begin{tabular}{|l|l|l|l|l|l|l|l|l|}
\hline Geographical Areas & \multicolumn{2}{l}{ AlAhram } & \multicolumn{2}{l|}{ Aljumhurayea } & \multicolumn{2}{l|}{ Total } \\
\hline \multirow{2}{*}{ Local } & No. & $\%$ & No. & $\%$ & No. & $\%$ & No. & $\%$ \\
\cline { 2 - 11 } & 25 & 86 & 31 & 97 & 16 & 94 & 72 & $\mathbf{9 2 . 3}$ \\
\hline Arabic & 0 & 0 & 0 & 0 & 0 & 0 & 0 & $\mathbf{0}$ \\
\hline International & 4 & 14 & 1 & 3 & 1 & 6 & 6 & $\mathbf{7 , 6}$ \\
\hline Total & 29 & $100 \%$ & 32 & $100 \%$ & 17 & $100 \%$ & 78 & $\mathbf{1 0 0}$ \\
\hline
\end{tabular}

\section{From the above table:}

The local issues occupied the first place, and then came the international ones. Arab issues were not dealt with by the infographic although they are many and related to the local issues.

International issues were given the highest attention on the electronic portal of AlAhram. The studies of both Abeer Salem \& Jawad Raghib agree upon the fact that local issues occupy the front rank of all issues covered by infographics.

Types of the Infographic

The design of the infographic is divided into the

following:

- Motionless

- Motional

- Interactive

First type, Motionless Infographics:

It explains complicated information and affects readers quickly and instantly.

\section{Second type, Motional Infographics:}

It presents information in a serial way. Videotaping:

It comes with data on it in a graphical motional way which helps to transfer some facts and concepts, but not profusely used.

\section{The design of motional infographics:}

All data and information are designed to be completely motional which requires a lot of creation and choice of expressive motion, the thing that guarantees an interesting and exciting piece of work. Besides, such a type of infographic always has specific scenario that need direction, and it is the most used type.

Third type, Interactive infographic:

It is the type that enables readers to participate in choosing the information and picking up what is useful for presentation. (Mahmoud Shaltot, 2015)

Table.3: Type of infographic according to its design:

\begin{tabular}{|l|l|l|l|l|l|l|l|l|}
\hline Type & No. & $\%$ & No. & $\%$ & No. & $\%$ & No. & $\%$ \\
\hline Motionless & 29 & 100 & 29 & 90.6 & 17 & 100 & 72 & 92.3 \\
\hline Motional & - & - & 3 & 9.4 & - & - & - & - \\
\hline Interactive & - & - & - & - & - & - & - & - \\
\hline Total & 29 & $100 \%$ & 32 & $100 \%$ & 17 & $100 \%$ & 78 & $100 \%$ \\
\hline
\end{tabular}

It is clear from the above table that all the electronic portals of the national press basically counts on motionless infographic with the exception of the portal of AkhbarAlyoum that used infographics by $9.4 \%$ only. Motionless infographics explains the given information instantly and does not include as much and deep detail as the motional one. As for the interactive infographics, although it allows readers to participate in the content, Miltaz 2013 proved that there was no link between it and the comprehensive recovery of information.
MeanwhileGiardina\& Medina proved right the opposite as it improves the capabilities of the news readership.

Types of infographic in terms of content:

-Ideas \& concepts

-Data presentation

-Pictures \& images

-Data analysis

-Chronology 
Table.4: Types of infographic in terms of contents

\begin{tabular}{|l|l|l|l|l|l|l|l|l|}
\hline \multirow{2}{*}{$\begin{array}{l}\text { Types of infographics } \\
\text { in terms of content }\end{array}$} & \multicolumn{2}{|l|}{ AlAhram } & \multicolumn{2}{l|}{ AlAkhbar } & \multicolumn{2}{l|}{ Aljumhurayea } & \multicolumn{2}{l|}{ Total } \\
\cline { 2 - 10 } & No & $\%$ & No & $\%$ & No & $\%$ & No & $\%$ \\
\hline Presentation of ideas & 17 & 59 & 22 & 69 & 10 & 59 & 49 & 62.8 \\
\hline Comparisons & 5 & 17 & 7 & 22 & 5 & 29 & 17 & 21.8 \\
\hline Images & 3 & 10 & 1 & 3 & 2 & 12 & 6 & 7.7 \\
\hline Chronology & 2 & 7 & 2 & 6 & 0 & 0 & 4 & 5.1 \\
\hline Data analysis & 2 & 7 & 0 & 0 & 0 & 0 & 2 & 2.6 \\
\hline Total & 29 & 100 & 32 & 100 & 17 & 100 & 78 & 100 \\
\hline
\end{tabular}

It is clear from the above table that:

While the most used type of infographic on the sample study is "Presentation of ideas" which presents only the information without explanation, the type of "data analysis" came last and completely disappeared on the portal of AlAkhbarAlyoum and Aljumhurayea all over the period of study, and AlAhram used a little of it. economic development issues. (Ubaida 2009) And that caused the readership being careless about what was behind figures or chasing more data on other portals, the thing that contradicts the core profession of mass mediawhich is explanation and analysis. That type simplifies the information and makes it understandable by just presenting the overall amount of information in brief.

The study of Ubaida proved that journalism paid more attention to the quantity than the quality of covering the

Table.5: Sources of infographic

\begin{tabular}{|l|l|l|l|l|l|l|l|l|}
\hline \multicolumn{2}{l|}{ Sources } & \multicolumn{2}{l|}{ AlAhram } & \multicolumn{2}{l|}{ AlAkhbar } & \multicolumn{2}{l|}{ Aljumhurayea } & \multicolumn{2}{l|}{ Total } \\
\hline $\begin{array}{l}\text { Government (Bodies, } \\
\text { ministries, }\end{array}$ & No & $\%$ & No & $\%$ & No & $\%$ & No & $\%$ \\
\cline { 2 - 10 } & $\mathbf{2 9}$ & $\mathbf{1 0 0}$ & $\mathbf{3 2}$ & $\mathbf{1 0 0}$ & $\mathbf{1 7}$ & $\mathbf{1 0 0}$ & $\mathbf{7 8}$ & $\mathbf{1 0 0}$ \\
\hline Internal sources & $\mathbf{0}$ & $\mathbf{0}$ & $\mathbf{0}$ & $\mathbf{0}$ & $\mathbf{0}$ & $\mathbf{0}$ & $\mathbf{0}$ & $\mathbf{0}$ \\
\hline $\begin{array}{l}\text { External sources } \\
\text { (outside the portal) }\end{array}$ & $\mathbf{0}$ & $\mathbf{0}$ & $\mathbf{0}$ & $\mathbf{0}$ & $\mathbf{0}$ & $\mathbf{0}$ & $\mathbf{0}$ & $\mathbf{0}$ \\
\hline Total & $\mathbf{2 9}$ & $\mathbf{1 0 0}$ & $\mathbf{3 2}$ & $\mathbf{1 0 0}$ & $\mathbf{1 7}$ & $\mathbf{1 0 0}$ & $\mathbf{7 8}$ & $\mathbf{1 0 0}$ \\
\hline
\end{tabular}

It is clear from the above table that:

All the electronic portals, the sample study, relied on the government sources only, the thing that made readers doubt their integrity and honesty as the issues in question were dealt with from one point of view, and were biased in favor of the government only.

Table.6: Attraction of colors in the design of the infographics

\begin{tabular}{|l|c|c|c|c|c|c|c|c|}
\hline \multirow{2}{*}{$\begin{array}{l}\text { Using colors in } \\
\text { the design }\end{array}$} & \multicolumn{2}{|l|}{ AlAhram } & \multicolumn{2}{l|}{ AlAkhbar } & \multicolumn{2}{l|}{ Aljumhurayea } & \multicolumn{2}{l|}{ Total } \\
\cline { 2 - 9 } & No & $\%$ & No & $\%$ & No & $\%$ & No & $\%$ \\
\hline $\begin{array}{l}\text { Matching of } \\
\text { colors }\end{array}$ & 24 & 83 & 30 & 94 & 14 & 82 & 68 & 87.2 \\
\hline $\begin{array}{l}\text { Mismatching of } \\
\text { colors }\end{array}$ & 5 & 17 & 2 & 6 & 3 & 18 & 10 & 12.8 \\
\hline Total & 29 & 100 & 32 & 100 & 17 & 100 & 78 & 100 \\
\hline
\end{tabular}

The electronic portals, the sample study, used colors harmoniously by $87.2 \%$. AlAkhbarAlyoum was the top in that regard by $94 \%$. 
Table.7: Matching of images in the design of the infographic:

\begin{tabular}{|c|c|c|c|c|c|c|c|c|}
\hline \multirow[t]{2}{*}{ Use of images } & \multicolumn{2}{|c|}{ AlAhram } & \multicolumn{2}{|c|}{ AlAkhbar } & \multicolumn{2}{|c|}{ Aljumhurayea } & \multicolumn{2}{|l|}{ Total } \\
\hline & No & $\%$ & No & $\%$ & No & $\%$ & No & $\%$ \\
\hline Matching of images & 27 & 93.1 & 31 & 97 & 17 & 100 & 44 & 93.6 \\
\hline $\begin{array}{l}\text { Mismatching of } \\
\text { images }\end{array}$ & 2 & 6.9 & 1 & 3 & $\mathbf{0}$ & $\mathbf{0}$ & 3 & 6.9 \\
\hline Total & 29 & 100 & 32 & 100 & 17 & 100 & 47 & 100 \\
\hline
\end{tabular}

Images were harmoniously used on all electronic portals, the sample study. AlAhram was the top in that regard by $100 \%$.

Table.8: Coherence of the design basics (Unity, Motion, Proportion, Discrepancy) of the infographic

\begin{tabular}{|c|c|c|c|c|c|c|c|c|}
\hline \multirow{2}{*}{$\begin{array}{l}\text { Setting the basics } \\
\text { of the design }\end{array}$} & \multicolumn{2}{|c|}{ AlAhram } & \multicolumn{2}{|c|}{ AlAkhbar } & \multicolumn{2}{|c|}{ Aljumhurayea } & \multicolumn{2}{|c|}{ Total } \\
\hline & No & $\%$ & No & $\%$ & No & $\%$ & No & $\%$ \\
\hline $\begin{array}{l}\text { Coherent design } \\
\text { (keeps the basics } \\
\text { of the design }\end{array}$ & 27 & 93 & 32 & 100 & 17 & 100 & 76 & 97.4 \\
\hline $\begin{array}{l}\text { Incoherent design } \\
\text { ( does not keep } \\
\text { the basics of the } \\
\text { design) }\end{array}$ & 2 & 7 & $\mathbf{0}$ & $\mathbf{0}$ & $\mathbf{0}$ & $\mathbf{0}$ & 2 & 2.6 \\
\hline Total & 29 & 100 & 32 & 100 & 17 & 100 & 29 & 100 \\
\hline
\end{tabular}

It is clear from the table above that:

The design is coherent and highly fulfils the required basics of the design by (97.4\%), and 2.6\% incoherent. The websites of AlAkhbarAlyoum and Aljumhurayea both achieved coherence by $100 \%$ which means the websites of the sample study are keen to achieve coherence and keep the basics of designing infographic.

Table.9: Used methods of presentations

\begin{tabular}{|l|c|c|c|c|c|c|c|c|}
\hline \multirow{2}{*}{ Type of Method } & \multicolumn{2}{|c|}{ AlAhram } & \multicolumn{2}{c|}{ AlAkhbar } & \multicolumn{2}{c|}{ Aljumhurayea } & \multicolumn{2}{c|}{ Total } \\
\cline { 2 - 9 } & No & $\%$ & No & $\%$ & No & $\%$ & No & $\%$ \\
\hline Statement Method & 7 & 24 & 17 & 53 & 15 & 88 & 39 & 50 \\
\hline $\begin{array}{l}\text { Commercial } \\
\text { Method for the } \\
\text { government }\end{array}$ & 17 & 59 & 10 & 31 & 2 & 12 & 29 & 37.2 \\
\hline Analysis Method & 5 & 17 & 5 & 16 & 0 & 0 & 10 & 12.8 \\
\hline \multicolumn{1}{|c|}{ Total } & 29 & 100 & 32 & 100 & 17 & 100 & 78 & 100 \\
\hline
\end{tabular}

It is clear from the table above:

The infographics on the electronic portals largely relied on the statement method. As for the analysis method was the least used on them (by 12.8\%). Aljumhurayea never used the analysis method despite the importance of the infographic in analyzing information and data. Some news and issues are hard to understand, so they need analysis and explanation. The means of information becomes more effective by analyzing the overwhelming information that is full of details.(Jawad Ragheb 2018) 
Table.10: Visual elements of infographic

\begin{tabular}{|l|l|l|l|l|l|l|l|l|}
\hline \multirow{2}{*}{$\begin{array}{l}\text { Type of } \\
\text { infographic }\end{array}$} & \multicolumn{3}{|l|}{ AlAhram } & \multicolumn{2}{l|}{ AlAkhbar } & \multicolumn{2}{l|}{ Aljumhurayea } & \multicolumn{2}{l|}{ Total } \\
\cline { 2 - 10 } & No & $\%$ & No & $\%$ & No & $\%$ & No & $\%$ \\
\hline $\begin{array}{l}\text { Electronic } \\
\text { ready-made } \\
\text { images }\end{array}$ & 25 & 86 & 23 & 72 & 17 & 100 & 65 & $\mathbf{8 3 . 3}$ \\
\hline $\begin{array}{l}\text { Camers } \\
\text { pictures }\end{array}$ & 2 & 7 & 5 & 16 & 0 & 0 & 7 & $\mathbf{8 . 9}$ \\
\hline $\begin{array}{l}\text { Forms, maps, } \\
\text { arrows }\end{array}$ & 2 & 7 & 4 & 13 & 0 & 0 & 6 & $\mathbf{7 . 7}$ \\
\hline Total & 29 & 100 & 32 & 100 & 17 & 100 & 78 & $\mathbf{1 0 0}$ \\
\hline
\end{tabular}

It is clear from the table that:

The use of ready-made images increased to $83.3 \%$ and Aljmhurayea used them by $100 \%$. That type of images helped designers a lot and saved much time and effort although it cannot convey much of the messages to the audience. So it should not be largely used.
Forms, pictures and arrows were less used (by $7.7 \%$ ) although it is a simple way of presenting information to the common readers. They use few words, however they help make the information more memorable specially that of the economic development issues which count on many figures and terms.

Table.11: Reading elements of infographic

\begin{tabular}{|l|l|l|l|l|l|l|l|l|}
\hline \multirow{2}{*}{$\begin{array}{l}\text { Reading } \\
\text { elements }\end{array}$} & \multicolumn{2}{|l|}{ AlAhram } & \multicolumn{2}{l|}{ AlAkhbar } & \multicolumn{2}{l|}{ AlJumhurayea } & \multicolumn{2}{l|}{ Total } \\
\cline { 2 - 9 } & No & $\%$ & No & $\%$ & No & $\%$ & No & \% \\
\hline $\begin{array}{l}\text { Figures \& } \\
\text { statistics }\end{array}$ & 19 & 66 & 23 & 72 & 5 & 29 & 47 & 60.3 \\
\hline $\begin{array}{l}\text { Information \& } \\
\text { facts }\end{array}$ & 10 & 34 & 9 & 28 & 12 & 71 & 31 & 39.7 \\
\hline Total & 29 & 100 & 32 & 100 & 17 & 100 & 78 & 100 \\
\hline
\end{tabular}

It is clear from the table above that:

Statistics and figures came in the first place and was noted to be the most used on the study websites. AlAkhbarAlyoum recorded the highest percentage (72\%) and this matches (Dick 2014)

Meanwhile, Aljumhurayea focused more on presenting information and facts to be in the first place by $(71 \%)$.In general, visual and reading materials are usually complementary for ordinary readers to understand all the data smoothly.

\section{SUMMARY \& DISCUSSION}

The study has analyzed the ways used by the infographic on the electronic portals in dealing with the economic development issues. The study used statistical tables for comparing the study websites in terms of the infographic types of content, design, sources of information, geographical areas, components, coherence of design, matching of colors and matching of images and pictures with the topics in question.

\section{CONCLUSION}

All study websites agreed upon:

-The use of infographic on the electronic portals of the national press is less than expected as against the need of the readership in the digital age.

-The government sources of information are only used.

-The local issues come first.

- There is no focus on the economic development issues in the Arab world.

- Dealing with the economic development issues in terms of their quantity rather than quality.

-Presentation of figures and statistics without analysis of data. 
-The electronic ready-made images come first in the study sample and then come the matching of colors, the matching of images with the topics and the coherence of the infographic design.

These conclusions came in the same line with other studies on the infographics such as the study of (Ismail Ibrahim, 2015) which proved that the infographics was poorly used on the national press websites, the study of (Dick 2014) which proved that figures and statistics was in the first rank, and the studies of Jawad Ragheb 2018 and Abeer Saleem 2018 which proved that the infographics paid the most attention to local issues.

\section{Each study website was distinguished by:}

-AlAhram website: It had the advantage of dealing with international issues but by only 14\%, Also, it used data analysis by $7 \%$ only.

-AlAkhbarAlyoum website: It excelled at the motional infographic but only 3 times all over the study.

-AlJumhurayea website: It excelled at utilizing the topographic elements so colors appeared as matching, pictures and images were matching with the topics and the design was more coherent than others on the websites.

\section{Notes}

-The infographic on the Arab websites is still poor, few and not up to the needs of the digital media audience.

-The infographic of the Arabic studies and researches is not enough and not satisfactory.

-The websites of the national press were targeted by researchers as they depend on the government sources, and were biased in favor of the government views.

- Infographic integrates the editorial aspects and the topographical aspects. Therefore, in our design of the analysis form, we have included the two sides to have a fairly fair evaluation.

\section{REFERENCES}

[1] Abdel Gawad Said Mohamed, The role of the Egyptian press in prioritizing the issues of rural public opinion, April 2014, dalyab848.blogspot.com

[2] Abeer Mohammed Selim, The Palestinian Web Directory of Comparative Analytical Study, Palestine, The Palestinian Open Education and E-Learning, vol. VI, twelfth issue, January 2018.

[3] Ahmed Fathi, The credibility of the press article presented in the Egyptian electronic news bulletin and its relation to the reader, MA, (Faculty of Information, Cairo University, 2017

[4] Alberto Cairo, The Functional Art: an introduction to information graphics and Visualization,(USA,pup . New Rider ,2013) p219
[5] Al-Manofiya University, Faculty of Arts, Department of Information, 2013), published a comparative study between the British Financial Times, The Egyptian Today, June 2009 to June 2011.

[6] Banu lnancUyanDur, interactive infographics on the internet, Online journal of Art and Design, Volume 2, issue 4,2014 , page 2

[7] EdlatAbdelmouti El Sheikh, The Role of Palestinian ENewspapers in Prioritizing Local Economic Issues, Unpublished MA, Press Section, Islamic University of Gaza, 2015.

[8] EisayedBekhit, infographics in the unit Arab Emirates newspaper,(journalism,vol .10(4), 2009.

[9] Faris Rachid Al-Bayati, Political Development in the Arab World, unpublished PhD (Arab Open Academy, Denmark, Amman, 2018.

[10] Finberg ,H\&Ltule, B , Visualediting: A Graphic Guide for journalists .(California, Wadsworth,Inc.1990)p.121

[11] Ismail Ibrahim, Journalism and Political Development, Cairo: Dar al-Kitab al-alami for publication and distribution, 1998.

[12] Ismail Ibrahim, Specialist Journalist, Cairo: Dar Al Fajr Publishing and Distribution, I, 2001.

[13] Ismail Ibrahim, Journalism Specialist, Cairo: Dar al-Fajr, 2, 2012.

[14] Ismail Ibrahim Rahil, The Infographic and his Role in Transferring the Events of the Revolution of January 25, 2011, Applied Study on Al-Ahram and Al-Masry Al-Youm Newspaper, Menoufia University, Journal of Faculty of Arts Research, Year 25 Issue 101 April, 2015.

[15] Jawad Ragheb Al-Dalu, The Infographic in the Palestinian Press, A Case Study for Al-Risala, Journal of Islamic University for Human Studies, No. 2, 2/2018, pp. $26: 1$.

[16] Katelyn Godoy, GreetingA complex Infographic about the yanelly Hill Widfire, a master of science Degree ,State university of New york ,2015.

[17] Mahmoud Shaltout, The Art of Infographic between Thrill and Motivation on Education, Arabic Infographic Website, available on 26-8-2015, available at: http: //arinfographic.net//p=1198/DanielAdams

[18] Mahmoud Youssef, Economic and Social Development, Faculty of Economics, 2017.

[19] Marco Giardina and Pablo media, Information Graphics Design challenges and Workflow Management, international Conference on Communication Media Technology and Design "ICCMTD", 9-11 May 2012.istanbul- Turkey

[20] Maren Volsdalskirbekk, the current state of graphics in british newspaper and news magazines, dissertataio submitted in the partial fulfillments of the requirements of the master of arts in information design ,UK: University of Reading, department of typography \& graphic communicathon, 2011.

[21] Marvin Milatz, moving Graphics : The Effectes of inter active infographics on media users, Recall Accuracy, Master's Thesis ,Erasmus mundus master journalism: media and Globalization, 2013. 
[22] Meir, G. \& Baldwin, R. (1962) Economic Development, 4th edition, Wily and Sons Inc., NY, USA.Mike Parkinson, The power of Visual Communication, retrieval at http:www.billiondollargraphics.com/info-graphics.html

[23] Murray Dick ,Interactive infographics and News values, Digital journalism, Volume 2, issue 4 ,2014, page 290- 506

[24] Munir Hijab, The Information Dictionary, Cairo: Dar Al Fajr Publishing and Distribution, First Edition, 2004) p. 17

[25] Newspaper, department of Government and STICERD London school of economics, November 2010.

[26] Saleh Hossam El-Din, Role of the Economic Press in Development in Sudan, MA, 2014, Sudan, Omdurman Islamic University.

[27] Tishreen, Lattakia, Syria. United Nations website, available at: www.un.org/millenniumgoals/bkgd.shtmi

[28] Umaimah Magdy Mohamed Zaki, frameworks dealing with the issues of the Egyptian economy in international and local economic journalism, Unpublished MA, Department of Journalism, Faculty of Media, Cairo University, 2012.

[29] VaientionLarcinese\& others , partism Bias in economic News:Evidence on the Agenda- setting Behavior of U.S. WaralakSiricharoen\&NattanunSiricharoen, How infographic Should be Evaluated?, The 7th International Conference on information Technology, Jordan: Am-man ,Volume : ISSN2306-6105.

[30] WaralakSiricharoen infographics: The New Communication Tools in Digital Age, The International conference on ETechnologies and Business on the Web (EBW2013)Thailand page 169-174

[31] http:llwww.scholar.harvard.edu/files/isnyder/files/2.partisan bis.usnewspaper.o.pdf 